\title{
Correction to: Understanding Living Conditions and Deprivation in Informal Settlements of Kisumu, Kenya
}

\author{
Sheillah Simiyu ${ }^{1,2} \cdot$ Sandy Cairncross $^{3} \cdot$ Mark Swilling $^{1}$
}

Published online: 8 January 2019

(C) The Author(s) 2019

\section{Correction to: Urban Forum \\ https://doi.org/10.1007/s12132-018-9346-3}

The article Understanding Living Conditions and Deprivation in Informal Settlements of Kisumu, Kenya, written by Sheillah Simiyu, Sandy Cairncross and Mark Swilling, was originally published electronically on the publisher's internet portal (currently SpringerLink) on October 20, 2018 without open access.

With the author(s)' decision to opt for Open Choice the copyright of the article changed on December 2018 to (C) The Author(s) 2018 and the article is forthwith distributed under the terms of the Creative Commons Attribution 4.0 International License (http://creativecommons.org/licenses/by/4.0/), which permits use, duplication,

The online version of the original article can be found at https://doi.org/10.1007/s12132-018-9346-3

Sheillah Simiyu

Sheillahshie@gmail.com

Sandy Cairncross

Sandy.Cairncross@1shtm.ac.uk

Mark Swilling

Mark.Swilling@spl.sun.ac.za

1 School of Public Leadership, Stellenbosch University, Private bag X1, Matieland,

Stellenbosch 7602, South Africa

2 Present address: Present address: Great Lakes University of Kisumu, P.O Box 2224-40100, Kisumu, Kenya

3 Department of Disease Control, London School of Hygiene and Tropical Medicine, Keppel Street, London WC1E 7HT, UK 
adaptation, distribution and reproduction in any medium or format, as long as you give appropriate credit to the original author(s) and the source, provide a link to the Creative Commons license and indicate if changes were made.

The original article has been corrected.

Open Access This article is distributed under the terms of the Creative Commons At tribution 4.0 International License (http://creativecommons.org/licenses/by/4.0/), which permits unrestricted use, distribution, and reproduction in any medium, provided you give appropriate credit to the original author(s) and the source, provide a link to the Creative Commons license, and indicate if changes were made.

Publisher's Note Springer Nature remains neutral with regard to jurisdictional claims in published maps and institutional affiliations. 